\title{
A comparison of gene transcription profiles of domesticated and wild Atlantic salmon (Salmo salar L.) at early life stages, reared under controlled conditions
}

\author{
Beatrix Bicskei ${ }^{1 *}$, James E Bron ${ }^{1}$, Kevin A Glover ${ }^{2}$ and John B Taggart ${ }^{1}$
}

\begin{abstract}
Background: Atlantic salmon have been subject to domestication for approximately ten generations, beginning in the early 1970s. This process of artificial selection will have created various genetic differences between wild and farmed stocks. Each year, hundreds of thousands of farmed fish escape into the wild. These escapees may interbreed with wild conspecifics raising concerns for both the fish-farming industry and fisheries managers. Thus, a better understanding of the interactions between domesticated and wild salmon is essential to the continued sustainability of the aquaculture industry and to the maintenance of healthy wild stocks.

Results: We compared the transcriptomes of a wild Norwegian Atlantic salmon population (Figgjo) and a Norwegian farmed strain (Mowi) at two life stages: yolk sac fry and post first-feeding fry. The analysis employed $44 \mathrm{k}$ oligo-microarrays to analyse gene expression of 36 farmed, wild and hybrid (farmed dam $x$ wild sire) individuals reared under identical hatchery conditions. Although some of the transcriptional differences detected overlapped between sampling points, our results highlighted the importance of studying various life stages. Compared to the wild population, the Mowi strain displayed up-regulation in mRNA translation-related and down regulation in nervous and immune system -related pathways in the sac fry, whereas up-regulation of digestive and endocrine activities, carbohydrate, energy, amino acid and lipid metabolism and down-regulation of environmental information processing and immune system pathways were evident in the feeding fry. Differentially regulated pathways that were common among life stages generally belonged to environmental information processing and immune system functional groups. In addition, we found indications of strong maternal effects, reinforcing the importance of including reciprocal hybrids in the analysis.

Conclusions: In agreement with previous studies we showed that domestication has caused changes in the transcriptome of wild Atlantic salmon and that many of the affected pathways are life-stage specific We highlighted the importance of reciprocal hybrids to the deconvolution of maternal/paternal effects and our data support the view that the genetic architecture of the strains studied highly influences the genes differentially expressed between wild and domesticated fish.
\end{abstract}

Keywords: Domestication selection, Microarray, Atlantic salmon, Gene expression, Farm escapees, Maternal effects

\footnotetext{
* Correspondence: bb20@stir.ac.uk

${ }^{1}$ Institute of Aquaculture, School of Natural Sciences, University of Stirling,

Stirling FK9 4LA, UK

Full list of author information is available at the end of the article
}

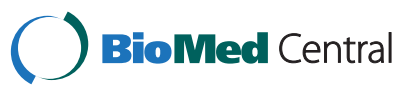

(c) 2014 Bicskei et al.; licensee BioMed Central Ltd. This is an Open Access article distributed under the terms of the Creative Commons Attribution License (http://creativecommons.org/licenses/by/4.0), which permits unrestricted use, distribution, and reproduction in any medium, provided the original work is properly credited. The Creative Commons Public Domain Dedication waiver (http://creativecommons.org/publicdomain/zero/1.0/) applies to the data made available in this article, unless otherwise stated. 


\section{Background}

Commercial Atlantic salmon (Salmo salar L.) aquaculture was first initiated in Norway during the late 1960s, and has grown rapidly to become one of the most economically significant global aquaculture industries (FAO 2013). Current world-production is around 2 million tonnes, with Norway, Chile and Scotland representing the three largest producers. While this industry has been highly successful in terms of expanding production and reaching new consumer markets, this has not been achieved without increasing the potential for environmental impact. The question of environmental impacts following the escape of farmed salmon, and in particular the potential for genetic interactions with wild conspecifics, continue to provide key themes for scientific debate and public controversy [1-3].

Thousands of farmed salmon are reported to escape from aquaculture installations on a regular basis and, due to the probability of underreporting [4-6], it has been estimated that the true number of escapees is likely to be significantly higher [7]. Depending upon several factors such as fish age and time of escapement $[8,9]$, some farmed salmon manage to survive in the wild and enter freshwater where native salmon populations reproduce. Farmed escapees have been observed on the spawning grounds of native populations in Norway $[10,11]$, the United Kingdom and Ireland [12-14], Iceland [15] Western Canada [16] and eastern North America [17]. While the reproductive success of farmed escapees is limited compared to wild salmon [18,19], farmed salmon have been observed spawning in the wild $[7,12,20]$, and genetic changes in native populations as a result of successful reproduction have been detected [21-24].

A recent study of historical and contemporary samples from 20 Norwegian salmon rivers estimated cumulative introgression of farmed escaped salmon in native populations [25]. Using a combination of single nucleotide polymorphisms (SNPs) and approximate Bayesian computation, these authors estimated introgression of farmed salmon reached nearly $50 \%$ in some rivers. This level of genetic introgression is of significant concern for two main reasons. First, wild Atlantic salmon populations are often genetically differentiated from one another and may be adapted to their specific rivers [26-29]. Thus, invasion of a non-local fish may disrupt local adaptation. Second, farmed Atlantic salmon have been subject to selection for a range of traits since breeding programs wer's [30-32]. As a result, farmed salmon display a range of genetic differences to wild Atlantic salmon in a number of measured traits; for example, greatly increased growth rates under farming conditions [33-36], reduced predator awareness [37], reduced genetic diversity in highly polymorphic genetic markers at the population level $[38,39]$, and altered gene-transcription patterns [40,41]. Furthermore, studies conducted in the wild have demonstrated that the offspring of farmed salmon display reduced survival compared to the offspring of wild salmon [19,42-44], an observation consistent with the reported lower fitness of the offspring of hatchery fish in the wild $[45,46]$. Studies of the genetic differences between wild and domesticated salmon therefore represent an important contribution towards gaining understanding of the likely evolutionary consequences of interbreeding between escaped salmon and their wild conspecifics.

Forty years ago King and Wilson proposed that gene regulation governs evolution of anatomy, physiology and behaviour $[47,48]$ and the development of broad-spectrum/ high-throughput genomic approaches allows the theory to be tested. DNA microarrays, for example, are commonly used to simultaneously measure the mRNA expression levels of thousands of transcripts and have been available for salmonids since 2004 [49,50]. As well as being employed to study genome-wide transcript expression, microarray experiments have been tailored to explore aspects of evolutionary processes, such as domestication in Atlantic salmon. In a series of microarray studies, Roberge and colleagues $[40,41]$ suggested that five to seven generations of selection for domestication may be sufficient to induce heritable alterations in transcription levels compared to wild populations. Of the differentially expressed genes that they detected, $16 \%$ displayed parallel changes among the strains, providing further evidence that artificial selection drives evolutionary changes at the gene transcription level [40]. Furthermore the authors suggested that, since most (82\%) of the differentially expressed genes exhibited non-additive inheritance patterns, the consequences of introgression would likely to be difficult to predict [41].

In the present study, microarray analysis was used to explore potential gene transcription/regulatory consequences of hybridisation between wild and domesticated salmon. In order to investigate genome wide transcript expression differences between wild and domesticated stocks, mRNA levels were compared for yolk-sac and externally feeding fry originating from wild (Figgjo), domesticated (Mowi) and hybrid (Mowi + x Figgjo $\widehat{\delta}$ ) populations reared under common conditions. Early life-history stages were focused upon, primarily to minimise transcriptional differences between the strains resulting solely from divergent interstrain growth rates (up to three fold difference by four months post first feeding [36]). Furthermore, sampling during perceived periods of major physiological perturbation, e.g. hatching and swim up stages, were avoided, as individual variation during transition periods is likely to be critically influenced by sample timing. Body size differences in fish have been linked to developmental stage divergence and transcriptomic differences have been detected between size and age matched wild rainbow trout. Hence the exact 
methods employed to match life stages of wild and domesticated fish could influence the genes identified as differentially expressed between the stocks [51]. With the aim of minimising the confounding factors described above, this study was designed to provide an insight into genetic differences and interactions between wild and domesticated salmon, since understanding such interactions is essential both for the support of sustainable aquaculture practices and for the maintenance of healthy wild stocks.

\section{Methods}

\section{Biological samples}

The farmed salmon juveniles used for the present study originated from the Norwegian Mowi strain maintained by Marine Harvest at Tveitevåg, Norway. This represents one of the oldest commercial salmon strains, and at the time of stripping, the eggs and sperm used to generate the family-groups originated from approximately the $10^{\text {th }}$ generation. The Mowi strain was initially selected for increased growth, late maturation and high flesh quality through phenotypic selection, however, a familybased breeding program which included expansion in the numbers of traits being selected for was initiated in 1999 [34]. The Mowi strain has been demonstrated to display freshwater growth rates several times higher than various wild populations $[34,36,52]$, and reduced survival compared to wild salmon under natural conditions when simultaneously planted out as eyed eggs [44].

The wild salmon used in this study originated from the Figgjo River in south west Norway. This population represents one of the most abundant in Norway, and is characterised by small to medium-sized fish (typically 12 sea winter returns). In the period $15-17^{\text {th }}$ October 2010, 24 wild fish were caught by rod and line angling in the river. These fish were transported to the local hatchery where they were held in tanks before being transported to the Matre research station in western Norway on $25^{\text {th }}$ October 2010. These fish were confirmed to be wild based upon scale growth patterns [53].

Both farmed and wild broodstock were stripped for gametes on $23^{\text {rd }}$ November 2010. A total of 30 families were created; 10 of each of the following crosses: pure wild, Figgjo $q \times$ Figgjo $\sigma^{\lambda}$; hybrid, Mowi $q \times$ Figgjo $\delta$; pure domesticated, Mowi $q \times$ Mowi $\hat{\jmath}$. Fertilised eggs were placed into single family incubators and were held under standard hatchery conditions. At the eyed egg stage on $22^{\text {nd }}$ February 2011, families were pooled into duplicate experimental groups, i.e. six tanks in total, and by $23^{\text {rd }}$ March 2011 half of the eggs had hatched, these being termed $0^{\circ} \mathrm{d}$ post-hatch. The first sampling took place during fry yolk-sac re-absorption $\left(256^{\circ} \mathrm{d}\right.$ posthatch) and then fish were transferred to heated $\left(13^{\circ} \mathrm{C}\right)$ first feeding tanks. Fry were fed on standard hatchery diet (Skretting) $24 \mathrm{hr}$ a day by automatic feeders according to a standard Skretting feeding table for appropriate temperatures. The second sampling took place 5 weeks into exogenous feeding $\left(867^{\circ} \mathrm{d}\right.$ post-hatch). The fish were starved for $24 \mathrm{hr}$ prior to the second sample. For both sampling time points fry were euthanised with metacaine (Finquel $^{\circledR}$ Vet, Scanvacc, Årnes, Norway) overdose, with yolk sac fry being placed into RNALater ${ }^{\bullet}$ (Life Technologies) and feeding fry being snap frozen on dry ice and stored at $-70^{\circ} \mathrm{C}$ until homogenised.

The experiment was conducted in accordance with Norwegian regulations for the use of animals in research. No specific permits were required for this experiment because the fish were hatched and reared under standard aquaculture conditions without any form of experimental manipulation.

\section{Microarray experimental design}

Microarray interrogations were performed using a custom-designed, oligonucleotide microarray platform (Agilent) with $44 \mathrm{~K}$ probes per slide (Salar_2; Agilent Design ID:025520). This microarray has been described in detail elsewhere [54] and further used/validated in a number of subsequent studies [55-57]. The design is logged with ArrayExpress (http://www.ebi.ac.uk/arrayexpress) under accession number A-MEXP-2065. Dual-label hybridisations were undertaken, with each experimental sample (Cy3 labelled) being competitively hybridised against a pooled reference control (Cy5 labelled) comprising equimolar amounts from each experimental RNA sample. The interrogations comprised 36 separate hybridisations; 3 states (wild $\times$ wild; farmed $\times$ wild, farmed $\times$ farmed $) \times 2$ timepoints (sac fry and fed fry) $\times 6$ biological replicates. A single array was excluded from the analysis as it failed quality filtering, hence only five pools of domesticated feeding fry were analysed (Table 1).

\section{RNA extraction and purification}

Whole fry $(\mathrm{N}=216)$ were homogenised rapidly in $8 \times$ volume Tri Reagent (Sigma-Aldrich ${ }^{\circledR}$, St. Louis, U.S.A.) using a Polytron mechanical homogeniser (Kinematica PT 1300 D, Lucerne, Switzerland) and the RNA extracted following the manufacturer's instructions. RNA quantity and quality were assessed by spectrophotometry (NanoDrop ND-1000, Thermo Scientific, Wilmington, U.S.A.) and agarose gel electrophoresis respectively. For each

Table 1 A representation of the experimental design; each biological replicate comprising equal quantities of RNA from six individuals

\begin{tabular}{|c|c|c|}
\hline & Sac fry & Feeding fry \\
\hline 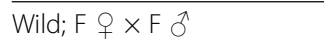 & 6 pools & 6 pools \\
\hline 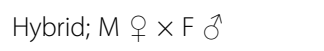 & 6 pools & 6 pools \\
\hline Domesticated; $M q \times M \curvearrowright ̋$ & 6 pools & 6 pools \\
\hline
\end{tabular}


hybridisation sample, equal amounts of total RNA from six individuals were pooled, column-purified (RNeasy Mini Kit, Qiagen, Crawley, UK), and then re-quantified and quality assessed as described above.

\section{RNA amplification and labelling}

Each pooled RNA sample was amplified (TargetAmp ${ }^{\text {tw }} 1$ Round Aminoallyl-aRNA Amplification Kit, Epicentre Technologies Corporation, Madison, Wisconsin, USA) according to the manufacturer's instructions. Following quality control (Nanodrop quantification and agarose gel electrophoresis) each aRNA sample was indirectly labelled and purified. Briefly, Cy dye suspensions (Cy3 and Cy5) in sufficient quantity for all labelling reactions were prepared by adding $40 \mu \mathrm{L}$ high purity dimethyl sulphoxide (Stratagene, Hogehilweg, The Netherlands) per tube of Cy dye (PA23001 or PA25001; GE HealthCare, Little Chalfont, Bucks, UK). Each sample ( $2.5 \mu \mathrm{g}$ aRNA) was denatured at $75^{\circ} \mathrm{C}$ for 5 min and then $3 \mu \mathrm{L} 0.5 \mathrm{M} \mathrm{NaHCO}_{3} \mathrm{pH} 8.5$ and $1.5 \mu \mathrm{L} \mathrm{Cy} 3$ or $1.0 \mu \mathrm{L}$ Cy5 dye was added achieving a total volume of $15 \mu \mathrm{L}$ per reaction. Samples were incubated for an hour at $25^{\circ} \mathrm{C}$ in the dark, purified using Illustra AutoSeq G-50 Dye Terminator Removal Kit (Qiagen GE Healthcare) and concentration, dye incorporation and purity were assessed via spectrophotometer (NanoDrop) with products also visualised on a fluorescent scanner (Typhoon Trio, GE Healthcare).

\section{Microarray hybridisation and quality filtering}

Hybridisation was performed over two consecutive days using the Agilent Gene Expression Hybridisation Kit (Agilent Technologies) as per manufacturer's instructions. For each reaction, 825 ng Cy5 labelled reference pool and $825 \mathrm{ng}$ Cy3 labelled individual samples were combined in $35 \mu \mathrm{L}$ nuclease free water and then $20 \mu \mathrm{L}$ fragmentation master mix added (consisting of $11 \mu \mathrm{L}$ of 10X blocking agent, $2 \mu \mathrm{L} 25 \times$ fragmentation buffer and $7 \mu \mathrm{L}$ nuclease free water). The reactions were then incubated at $60^{\circ} \mathrm{C}$ in the dark for 30 mins, chilled on ice, and mixed with $57 \mu \mathrm{L} 2 \times$ GEx Hybridisation buffer (pre heated to $\left.37^{\circ} \mathrm{C}\right)$, Following centrifugation $(18000 \times \mathrm{g}$ for $1 \mathrm{~min})$ the samples were kept on ice until loaded $(103 \mu \mathrm{L})$ in a semi randomised order onto the microarray slides. Samples from the six biological replicates were spread across different slides, $\mathrm{Cy} 3$ fluorescence content (dye incorporation rate $\times$ volume) was also taken into consideration. To aid scanning, samples with the most similar amounts of $\mathrm{Cy} 3$ were grouped on the same slide. Hybridisation was carried out in a rotating rack oven (Agilent Technologies) at $65^{\circ} \mathrm{C}, 10 \mathrm{rpm}$ over 17 hours.

Following hybridisation, slides were subject to a number of washing steps performed in Easy-Dip ${ }^{\text {twx }}$ slide staining containers (Canemco Inc., Quebec, Canada). First, each microarray and backing gasket was disassembled in
Agilent Wash Buffer 1 and microarray slides were transferred to an Easy Dip rack submerged in Wash Buffer 1. Following $1 \mathrm{~min}$ incubation at room temperature $\left(\right.$ c. $\left.20^{\circ} \mathrm{C}\right)$ and $150 \mathrm{rpm}$ (Stuart Orbital Incubator), slides were briefly dipped into Wash Buffer 1 pre-heated to $31^{\circ} \mathrm{C}$, then placed into Wash Buffer $2\left(31^{\circ} \mathrm{C}\right)$ for $1 \mathrm{~min}$ at $150 \mathrm{rpm}$. Finally, the slides were transferred to acetonitrile for $10 \mathrm{~s}$ and then Agilent Stabilization and Drying Solution for 30 s. The slides were then air dried in the dark and scanned within two hours.

Scanning was carried out at $5 \mu \mathrm{m}$ resolution on an Axon GenePix Pro scanner at 40\% laser power. The "auto PMT" function was enabled to adjust PMT for each channel such that less than $0.1 \%$ of features were saturated and so that the mean intensity ratio of Cy3:Cy5 signal was close to one. Agilent Feature Extraction Software ( $v$ 9.5) was used to identify features and extract background subtracted raw intensity values that were then transferred to GeneSpring GX (v.12) software where the quality filtering and normalisation steps took place. Intensity values $\leq 1$ were adjusted to 1 and a Lowess normalisation undertaken. Stringent quality filtering ensured that features that represented technical controls, saturated probes, probe population outliers or probes which were not significantly different from the background were removed. Agilent feature extractions software was used to determine whether a probe was positive and significant based on a 2 -sided $t$-test, indicating if the mean signal of a feature is greater than the corresponding background. A probe was retained if it was positive and significant in at least $75 \%$ of the arrays in any 2 of the experimental groups. This left 33,688 of the original 43,466 probes available for downstream analysis. A single array was excluded from the analysis as it was flagged as sub-standard by the feature extraction software and also appeared as a clear outlier on a Principal Component Analysis performed within Genespring in order to compare arrays. Thus 35 of the 36 arrays were statistically analysed.

Details of microarray experiment have been submitted to ArrayExpress under accession number E-MTAB2578. The recording of the microarray experimental metadata complies with Minimum Information About a Microarray Experiment (MIAME) guidelines.

\section{Microarray data analysis}

Differentially expressed genes between the crosses were identified in GeneSpring using a number of statistical methods and criteria. For the entire data analysis, life stages were treated separately and to identify differentially expressed genes between experimental groups pairwise Ttests (unpaired unequal variance, $\mathrm{p} \leq 0.01$ ) were performed and a minimum fold change of 1.3 applied. These lists formed the basis of the Venn diagram (Figure 1). In 


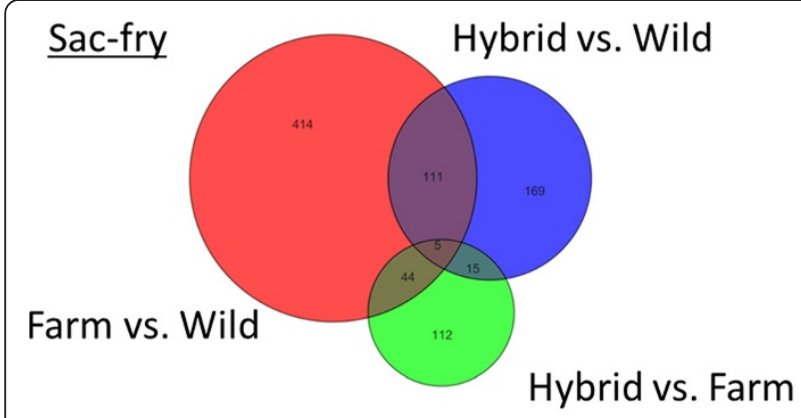

A

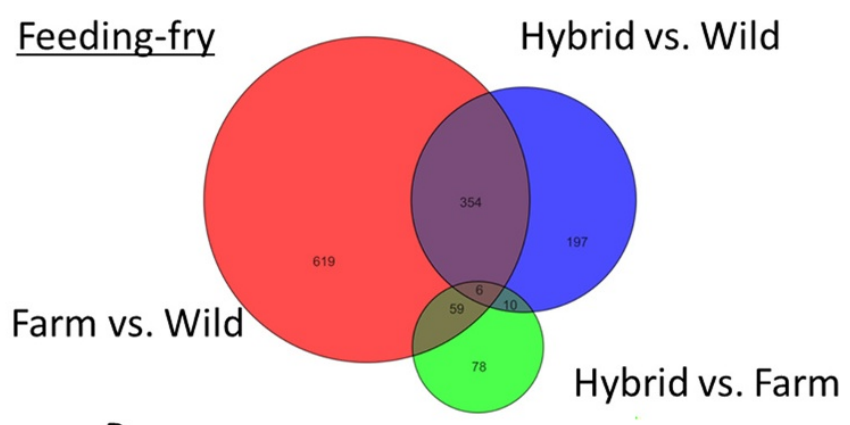

B

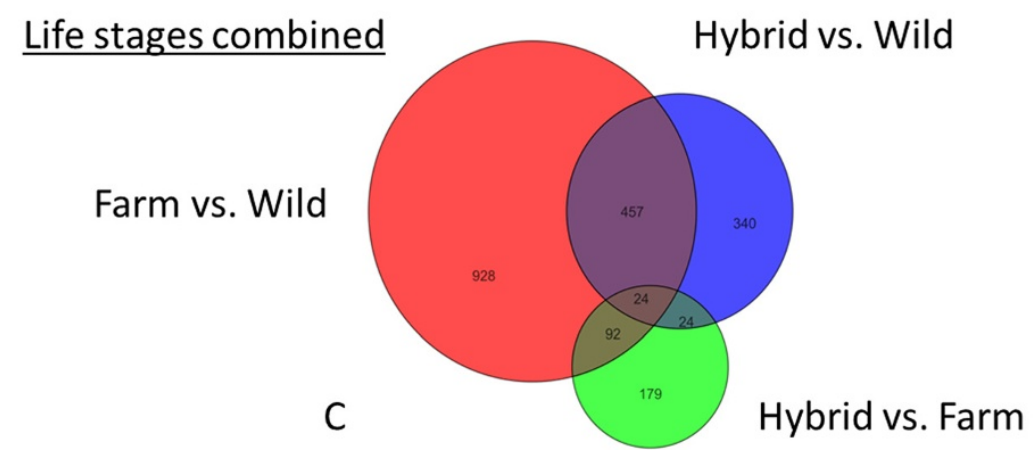

Figure 1 A comparison of the number of differentially expressed transcripts between groups and life stages, based on T-tests (unpaired unequal variance) without multiple testing correction, $\mathbf{p} \leq \mathbf{0 . 0 1}$ and fold-change cut off at $\mathbf{1 . 3}$. Panel $\mathbf{A}$ and $\mathbf{B}$ represent differences detected in the sac and feeding fry stage respectively, whereas panel $\mathbf{C}$ shows combined the differences; i.e.: each comparison is the union of the differences detected in the life stages.

contrast, the functional analysis of the genetic differences between wild and domesticated fish was based on less stringent criteria, with a $\mathrm{p} \leq 0.05$ and with no fold change requirement and were further analysed in $\mathrm{R}$ v.3.0.2 ( $\mathrm{R}$ Core Team, 2014). This enabled sufficient KEGG annotation for the pathway analysis which in turn narrowed the list of unique genes by further filtering on significant pathways using the gage function of the GAGE package (Generally Applicable Gene-set/Pathway Analysis) [55], $\mathrm{q} \leq 0.1)$ thereby increasing confidence despite the lenient initial comparison. The significant pathways (Table 2) were further analysed using the esset.grp and essGene functions [55] to identify non-redundant pathways and genes that changed over and above the noise level (Figures 2 and 3) respectively. Since pathways belonging to the human disease functional group are difficult to interpret in fish, this group was excluded from the gene enrichment analysis. Genes that were involved in any of the significantly perturbed pathways and changed beyond one standard deviation from the mean of all genes were subject to hierarchical clustering (Pearson correlation) and are presented on the heat maps using gplots package [56]. To look at heritability of differentially expressed genes between stocks, 1-way ANOVA (unequal variance) was performed with $10 \%$
FDR (Benjamini-Hochberg). To avoid repeat counting of the same gene, only transcripts that had BLASTx and/or KEGG annotation were chosen and where multiple probes were present for the same gene, the probe with the highest significance was chosen. For the unique genes obtained, additivity; $\alpha=$ (wild-domesticated) $/ 2$ and dominance parameters; $\delta=$ (wild + domesticated $) / 2$-hybrid were calculated from normalised intensity values and $\alpha$ and $\delta / \alpha$ were plotted using the ggplot2 package (Figure 4) [57].

\section{RT-qPCR validation}

Expression of five selected genes was validated using real time quantitative polymerase chain reaction (RT-qPCR). Genes of interest were chosen based on their p-values in either of the life stages and/or fold changes across experimental groups. Two additional 'housekeeping' genes were included in the analysis for normalisation purposes. Reference genes were selected from the literature or based on their constant/steady expression profile in the microarray analysis. Details of the selection criteria, primer design and RT-qPCR are given in (Additional file 1).

cDNA was synthesised from $1 \mu \mathrm{g}$ of column-purified total RNA per sample using the High-Capacity cDNA RT kit (Applied Biosystems, Paisley, U.K.), following manufacturer's instructions, but using a mixture of the random primers 
Table 2 Significantly differentially represented KEGG pathways (multiple testing corrected $p \leq 0.1$ ) between wild and domesticated stocks in the two life stages, wild fish is considered as control

\begin{tabular}{|c|c|c|c|c|c|c|}
\hline & KEGG functional group & KEGG sub-group & KEGG pathway & $\begin{array}{l}\text { Direction of } \\
\text { perturbation }\end{array}$ & $p$-value & Set size \\
\hline \multirow[t]{29}{*}{ Sac fry } & Cellular Processes & Cell growth and death & Oocyte meiosis & Up regulated & 0.00212 & 15 \\
\hline & $\begin{array}{l}\text { Environmental Information } \\
\text { Processing }\end{array}$ & Signal transduction & Hippo signaling pathway & Up regulated & 0.00128 & 15 \\
\hline & $\begin{array}{l}\text { Environmental Information } \\
\text { Processing }\end{array}$ & Signal transduction & Wnt signaling pathway & Up regulated & 0.00053 & 20 \\
\hline & $\begin{array}{l}\text { Genetic Information } \\
\text { Processing }\end{array}$ & $\begin{array}{l}\text { Folding, sorting and } \\
\text { degradation }\end{array}$ & $\begin{array}{l}\text { Protein processing in } \\
\text { endoplasmic reticulum }\end{array}$ & Up regulated & 0.00186 & 36 \\
\hline & $\begin{array}{l}\text { Genetic Information } \\
\text { Processing }\end{array}$ & Translation & Aminoacyl-tRNA biosynthesis & Up regulated & 0.00734 & 13 \\
\hline & $\begin{array}{l}\text { Genetic Information } \\
\text { Processing }\end{array}$ & Translation & Ribosome & Up regulated & 0.00016 & 50 \\
\hline & $\begin{array}{l}\text { Genetic Information } \\
\text { Processing }\end{array}$ & Translation & $\begin{array}{l}\text { Ribosome biogenesis in } \\
\text { eukaryotes }\end{array}$ & Up regulated & 0.00024 & 31 \\
\hline & $\begin{array}{l}\text { Genetic Information } \\
\text { Processing }\end{array}$ & Translation & RNA transport & Up regulated & 0.00002 & 39 \\
\hline & Cellular Processes & Transport and catabolism & Phagosome & Down regulated & 0.00042 & 37 \\
\hline & $\begin{array}{l}\text { Environmental Information } \\
\text { Processing }\end{array}$ & Signal transduction & NF-kappa B signaling pathway & Down regulated & 0.00093 & 25 \\
\hline & $\begin{array}{l}\text { Environmental Information } \\
\text { Processing }\end{array}$ & $\begin{array}{l}\text { Signaling molecules and } \\
\text { interaction }\end{array}$ & $\begin{array}{l}\text { Cytokine-cytokine receptor } \\
\text { interaction }\end{array}$ & Down regulated & $\leq 0.00001$ & 26 \\
\hline & Organismal Systems & Immune system & $\begin{array}{l}\text { B cell receptor signaling } \\
\text { pathway }\end{array}$ & Down regulated & 0.00133 & 16 \\
\hline & Organismal Systems & Immune system & Chemokine signaling pathway & Down regulated & $\leq 0.00001$ & 38 \\
\hline & Organismal Systems & Immune system & $\begin{array}{l}\text { Complement and coagulation } \\
\text { cascades }\end{array}$ & Down regulated & 0.00385 & 21 \\
\hline & Organismal Systems & Immune system & Fc epsilon RI signaling pathway & Down regulated & 0.00778 & 16 \\
\hline & Organismal Systems & Immune system & Hematopoietic cell lineage & Down regulated & 0.00007 & 14 \\
\hline & Organismal Systems & Nervous system & Glutamatergic synapse & Down regulated & 0.00152 & 19 \\
\hline & Organismal Systems & Nervous system & Serotonergic synapse & Down regulated & 0.00303 & 16 \\
\hline & Organismal Systems & Nervous system & Synaptic vesicle cycle & Down regulated & 0.00171 & 18 \\
\hline & Metabolism & Lipid metabolism & $\begin{array}{l}\text { Glycerophospholipid } \\
\text { metabolism }\end{array}$ & Down regulated & 0.00781 & 10 \\
\hline & $\begin{array}{l}\text { Environmental Information } \\
\text { Processing }\end{array}$ & Signal transduction & NF-kappa B signaling pathway & $\begin{array}{l}\text { Two way } \\
\text { perturbed }\end{array}$ & 0.00116 & 25 \\
\hline & $\begin{array}{l}\text { Environmental Information } \\
\text { Processing }\end{array}$ & Signal transduction & TNF signaling pathway & $\begin{array}{l}\text { Two way } \\
\text { perturbed }\end{array}$ & 0.00368 & 19 \\
\hline & $\begin{array}{l}\text { Environmental Information } \\
\text { Processing }\end{array}$ & $\begin{array}{l}\text { Signaling molecules and } \\
\text { interaction }\end{array}$ & $\begin{array}{l}\text { Cytokine-cytokine receptor } \\
\text { interaction }\end{array}$ & $\begin{array}{l}\text { Two way } \\
\text { perturbed }\end{array}$ & 0.00001 & 26 \\
\hline & $\begin{array}{l}\text { Environmental Information } \\
\text { Processing }\end{array}$ & $\begin{array}{l}\text { Signaling molecules and } \\
\text { interaction }\end{array}$ & $\begin{array}{l}\text { Neuroactive ligand-receptor } \\
\text { interaction }\end{array}$ & $\begin{array}{l}\text { Two way } \\
\text { perturbed }\end{array}$ & 0.00371 & 23 \\
\hline & Organismal Systems & Development & Osteoclast differentiation & $\begin{array}{l}\text { Two way } \\
\text { perturbed }\end{array}$ & 0.00555 & 28 \\
\hline & Organismal Systems & Immune system & Chemokine signaling pathway & $\begin{array}{l}\text { Two way } \\
\text { perturbed }\end{array}$ & 0.00343 & 38 \\
\hline & Organismal Systems & Immune system & $\begin{array}{l}\text { NOD-like receptor signaling } \\
\text { pathway }\end{array}$ & $\begin{array}{l}\text { Two way } \\
\text { perturbed }\end{array}$ & 0.00416 & 14 \\
\hline & Organismal Systems & Immune system & $\begin{array}{l}\text { Toll-like receptor signaling } \\
\text { pathway }\end{array}$ & $\begin{array}{l}\text { Two way } \\
\text { perturbed }\end{array}$ & 0.00240 & 19 \\
\hline & Metabolism & Lipid metabolism & $\begin{array}{l}\text { Glycerophospholipid } \\
\text { metabolism }\end{array}$ & $\begin{array}{l}\text { Two way } \\
\text { perturbed }\end{array}$ & 0.00275 & 10 \\
\hline
\end{tabular}


Table 2 Significantly differentially represented KEGG pathways (multiple testing corrected $p \leq 0.1$ ) between wild and domesticated stocks in the two life stages, wild fish is considered as control (Continued)

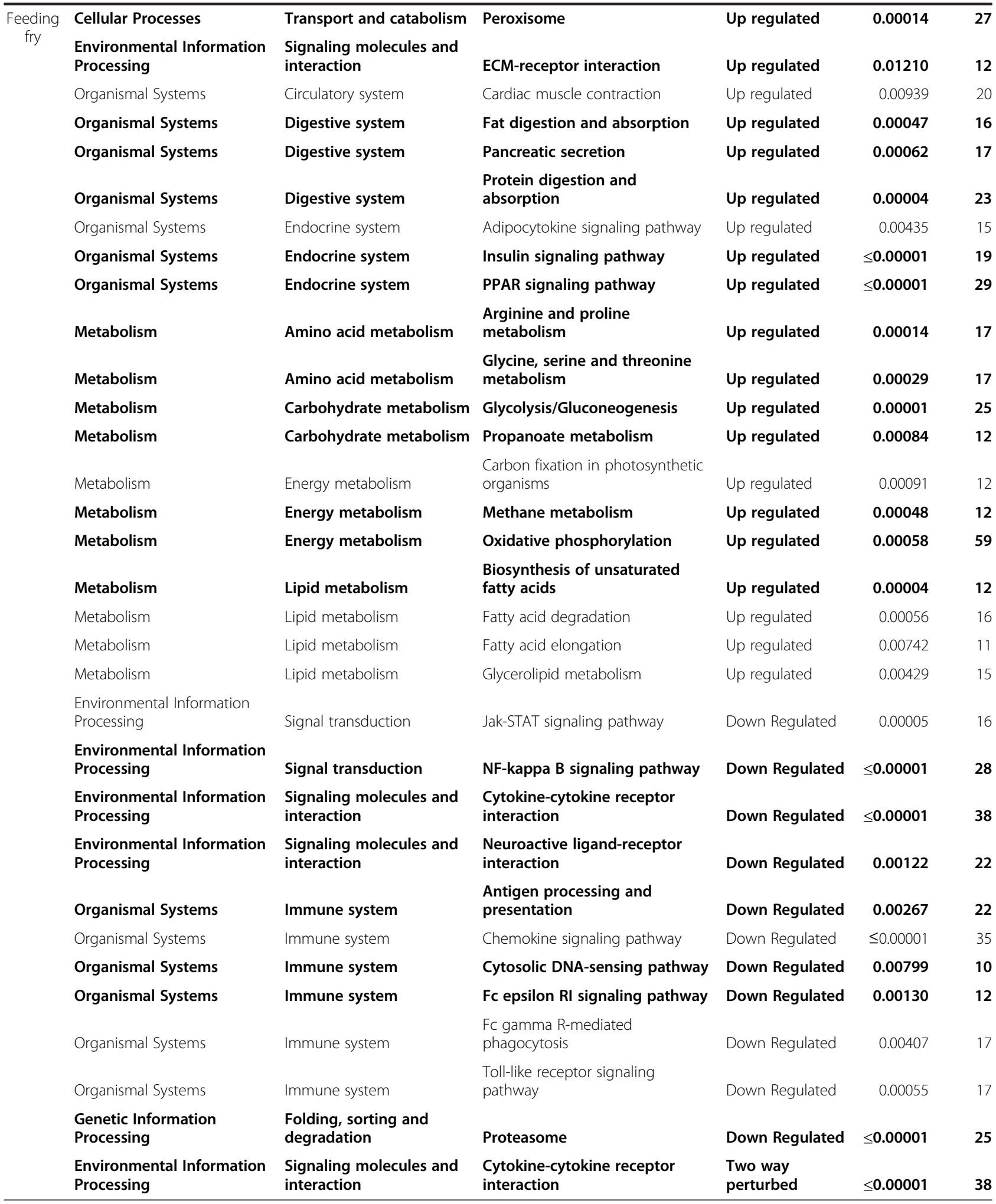

Set size is the number of genes included in the gene set test. Non-redundant pathways are shown in bold. 


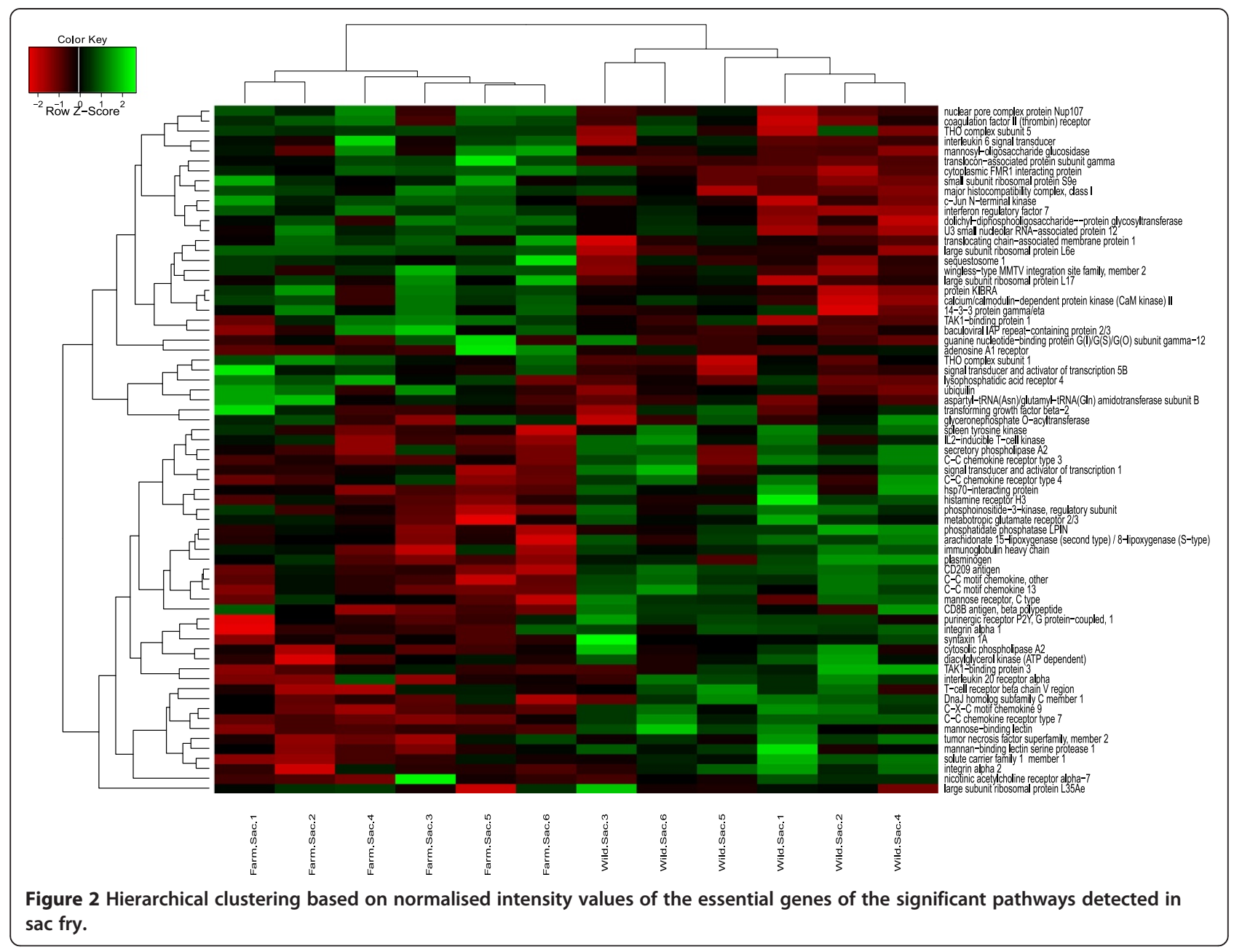

(1.5 $\mu \mathrm{L}$ as supplied) and anchored oligo-dT (0.5 $\mu \mathrm{L}$ at $400 \mathrm{ng} / \mu \mathrm{l})$. Negative controls lacking reverse transcriptase were included to check for genomic DNA contamination. A pool comprising similar amounts of all cDNA samples was used in a dilution series to determine primer efficiencies. The remaining CDNAs were then diluted 20 -fold in water.

qPCR amplifications were carried out in duplicate $20 \mu \mathrm{L}$ reaction volumes, containing either $5 \mu \mathrm{L}$ of cDNA $(1 / 20 \mathrm{di}-$ lution) or no enzyme control (1/20 dilution) or seriallydiluted cDNA pools (ranging from $1 / 10$ to $1 / 640$ dilution) or water (no template control) and $0.5 \mu \mathrm{M}$ each primer and $10 \mu \mathrm{L}$ ABgene Sybr Green (2×; Thermo Scientific, Wilmington, U.S.A.). All qPCR reactions were performed using the following thermal profile: initial activation at $95^{\circ} \mathrm{C}$ for $15 \mathrm{~min}$, amplification through 40 cycles of $95^{\circ} \mathrm{C}$ for $15 \mathrm{~s}, 60^{\circ}$ $\mathrm{C}$ for $15 \mathrm{~s}$ and $72^{\circ} \mathrm{C}$ for $30 \mathrm{~s}$. Following the amplification phase, a melt curve analysis was performed to confirm the amplification of a single product. In addition, to determine the size and identity of the amplicons, agarose gel electrophoresis of amplicons was undertaken. Data were analysed in REST 2009 software [58].

\section{Results and discussion}

Differentially expressed transcripts between strains and life stages

For the purposes of statistical analysis, life stages were treated separately. In order to identify differentially expressed genes between experimental groups, pairwise T-tests (unpaired unequal variance, $\mathrm{p} \leq 0.01$, fold change $\geq 1.3$ ) were used. The largest differences in transcription were observed between the domesticated and wild groups, however, it is interesting to note that there were fewer significantly differentially expressed transcripts between fish of hybrid and domesticated origin (176 in sac fry and 153 in feeding fry), than between wild and hybrids (300 and 567 respectively) (Figure $1 \mathrm{~A}$ and 1B). Maternal effects might have contributed to the bias, as hybrid eggs were originated from domesticated females. In addition to direct genetic effects from the yolk sac, such as highly abundant maternal ribosomes and maternally deposited RNAs, other yolk sac components, such as hormones, proteins or nutrients can influence the offspring's genomic activity by modifying or 


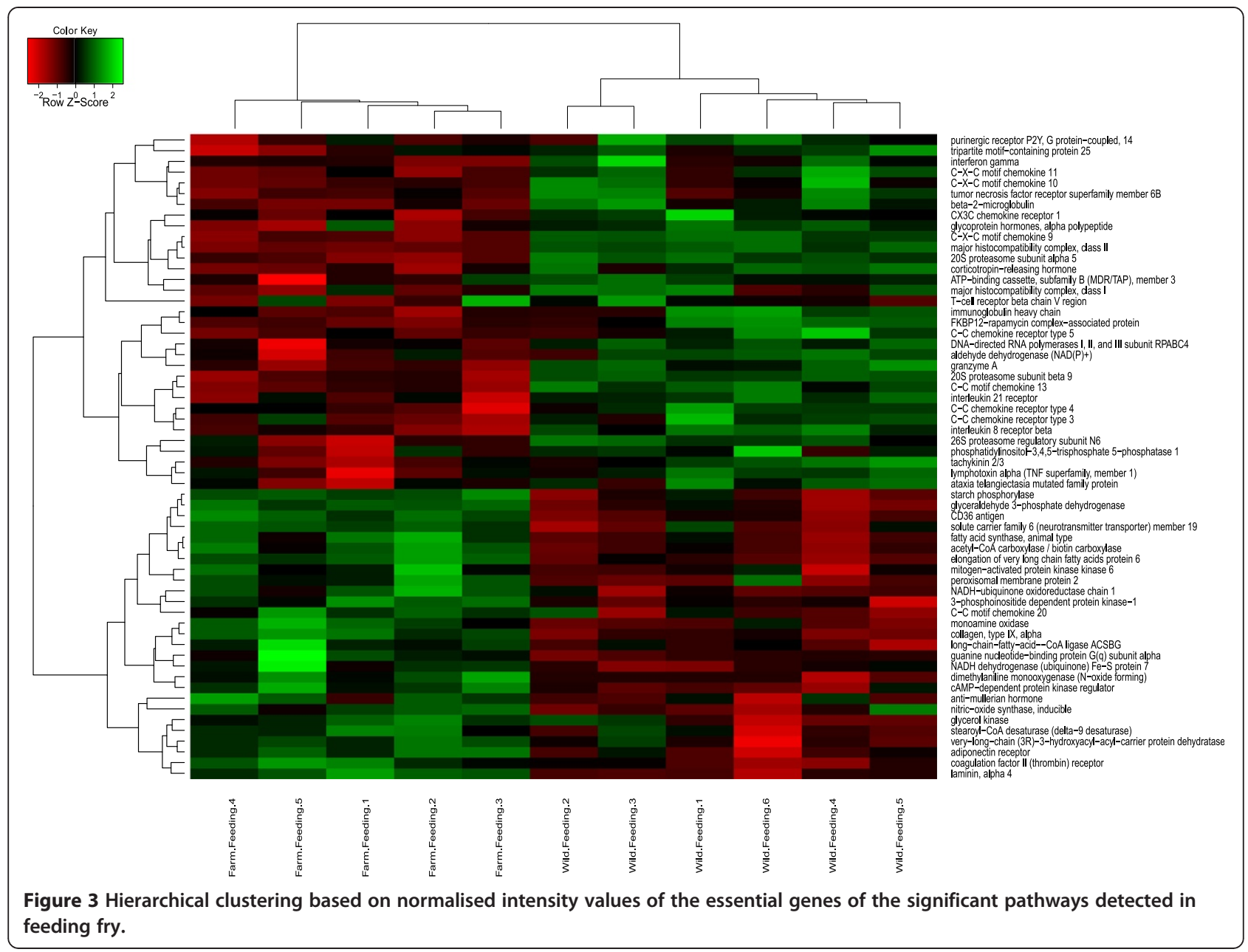

interacting with its transcription factors or DNA structure [59]. It was also noteworthy that there were over 1.8 times as many differentially expressed entities detected in the exogenous feeding stage than in the yolk-sac samples in the wild-domesticated and hybrid-wild comparisons (Figure 1). The initiation of exogenous feeding is known to alter gene expression through the activation of certain metabolic pathways, such as the glycolytic pathway enabling the utilisation of exogenous feeds or fatty acid pathways facilitating lipid metabolism and deposition [60]. This was reflected in the observation that differentially expressed genes belonging to carbohydrate and lipid metabolism pathways were common in feeding fry, but not in sac fry. Furthermore, the hatchery diet employed, containing plant derivatives and thus poorly matching the usual diet of wild fish, might affect gene expression differentially in wild and domesticated stocks, and may thereby account for some of the differences detected in the feeding stage. However, the initiation of exogenous feeding did not increase the number of differentially expressed transcripts between domesticated fish and their hybrids, despite the expected fading of maternal effects in later life stages [59]. Although some of the significantly differentially expressed genes overlapped between life stages, sampling at two time points revealed a number of life stage specific patterns (Figure 1C).

\section{Functional classification of differentially expressed genes between wild and domesticated strains}

It is difficult to make comparisons between studies at the level of differentially expressed genes due to the use of different stocks, life stages, tissues and microarray designs. Although common genes are rarely reported, biological pathways and even more so functional classes tend to overlap between studies [40]. To characterise the functional significance of the transcripts that were differentially expressed between wild and domesticated fish, we assigned KEGG annotations to them, unique genes were then subject to gene enrichment analysis (Table 2).

Transcriptional changes between wild and domesticated fish varied according to functional group life stage considered (Table 2). Among the differentially expressed transcripts, the ones relating to the immune system were 


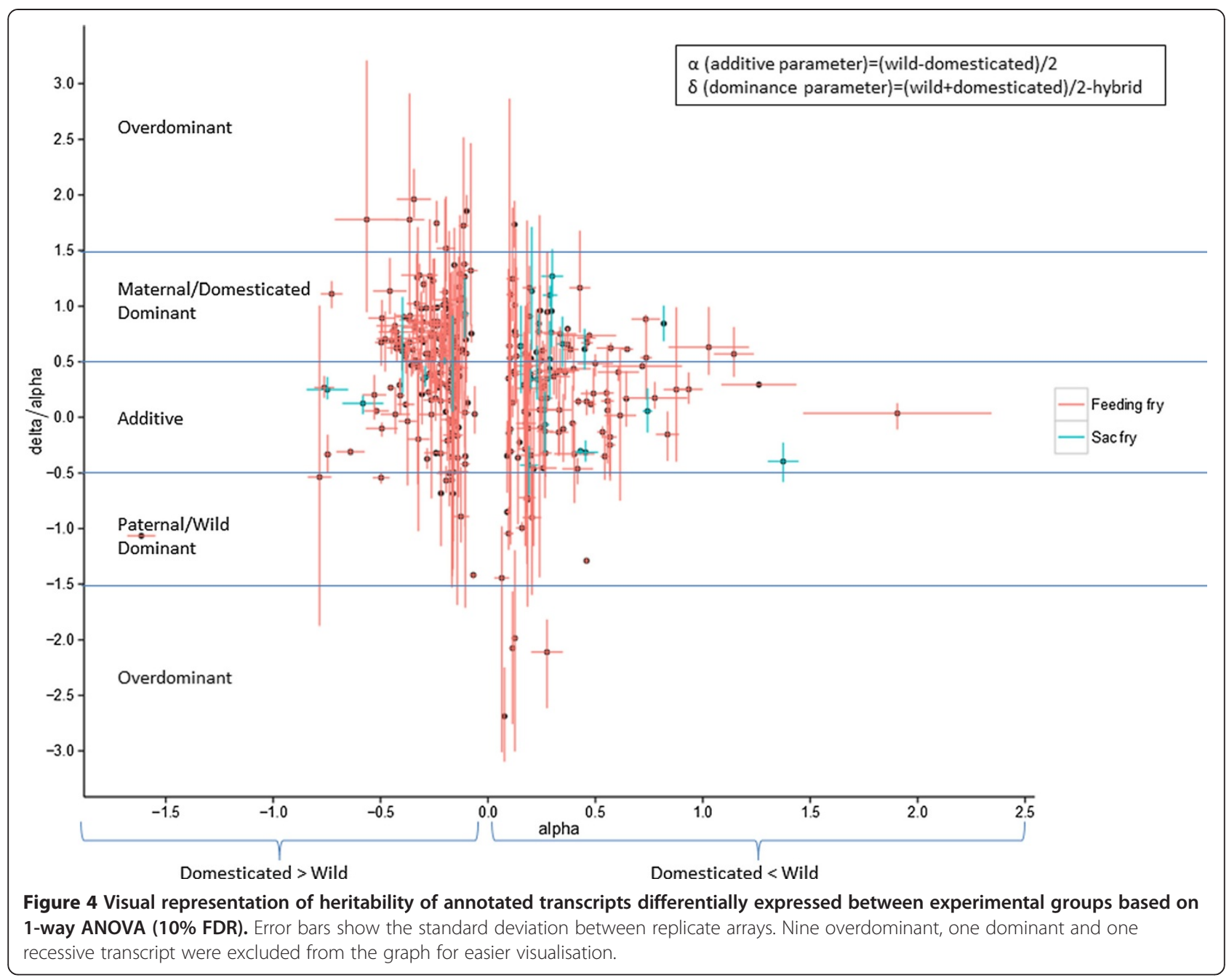

significantly over-represented in both life stages. In addition, disproportionately large numbers of differentially expressed transcripts were detected for the nervous and digestive systems in sac fry and feeding fry respectively (Table 2). An interesting parallel to this trend has been reported from transcriptomic comparisons between normal and dwarf lake white fish (Coregonus spp.), where the authors stressed the importance of survival functions in dwarf individuals and growth related functions in normal fish [61]. The majority of differentially expressed immune related transcripts were down-regulated in domesticated animals, whereas the opposite was observed for transcripts associated with the digestive system (Table 2). Such apparent trade-offs between growth and immune response have also been documented in Atlantic salmon by previous authors $[52,62]$. It has been suggested that selection for growth could therefore favour individuals with more active endocrine regulatory components [63] and this is supported by the findings that most differentially expressed transcripts relating to the digestive system showed higher expression in domesticated individuals as did endocrine system related transcripts (Table 2). In contrast, transcripts with nervous system and environmental information processing roles were mainly down-regulated in the domesticated strain, which might be explained by the relatively homogeneous and controlled environment experienced by domesticated individuals. Tymchuk and colleagues reported a down regulation of cell division in the brain of domestic rainbow trout, despite conducting their experiment on size-matched fish [64]. The relationship of wild : domesticated transcripts involved in energy metabolism, protein synthesis, stress and immune response, response to stimuli and digestion are in agreement between this study and previous studies investigating effects of domestication in salmonids $[40,41,51,65]$. Dishevelled Segment Polarity Protein 2 (DVL2), a member of the Wnt signalling pathway, was hypothesised in previous work to show footprints of selection through domestication in Atlantic salmon [66]. Although oligo probes for this particular gene were not incorporated in the design of Salar_2, the Wnt signalling pathway was significantly up regulated in the sac fry stage. 
A number of differentially expressed pathways were common between life stages, further increasing confidence in their significance. Toll-like receptor interaction, NF-kappa B signalling and cytokine-cytokine interactions pathways were down-regulated in the domesticated strain at both sampling points (Table 2). Toll-like receptors are primary sensors detecting a wide variety of microbial components and triggering innate immune responses through activating the transcription factor nuclear factorkappaB, which controls the expression of inflammatory cytokine genes [67]. Cytokines have the ability to regulate endocrine activity and stress hormones and, in addition to immune activation they are likely to play a role in a number of interrelated processes, such as food intake efficiency, energy balance and tissue metabolism [68], and could thus provide a linking element between the differentially expressed pathways identified in this study.

To visualise expression patterns of the key genes belonging to identified significant pathways, hierarchical clustering was performed and expression intensities are shown on heat maps for the two life stages (Figures 2 and 3). Although universal transcript-level differences have not been identified when studying different wild and domesticated strains, there are a small number of genes that have been reported to be differentially expressed by more than one study. Parallel changes included ATP synthase, growth hormone receptor [39], cytochrome this study, $[39,52,65]$, solute carrier family members (this study $[51,65]$ ), glyceraldehyde 3-phosphate dehydrogenase this study, [39] and malate/NADH dehydrogenase this study, [39,65]. A number of immune related transcripts such as lectin and various $C D$ and MHC family members were also reported by multiple sources, however their direction of change varies between studies this study, $[39,52,64,65]$. This might be due to the high specificity of the pathogen induced chemokine regulation [69].

\section{Heritability predictions of differentially expressed genes}

To shed light on the inheritance patterns of the genes differentially expressed between stocks gene expression additivity was studied. 1-way ANOVAs were performed with multiple testing corrections (corrected $\mathrm{p} \leq 0.1$ ) and only unique genes (see Methods for details); 25 in sac fry and 313 in feeding fry were included in the analysis (Additional file 2). By calculating the ratio of the dominance parameter, $\delta=($ wild + domesticated $) / 2$-hybrid and the additive parameter, $\alpha=$ (wild-domesticated) $/ 2$ one can estimate the inheritance pattern of genes from their expression values. By definition a transcript whose hybrid gene expression value corresponds to the mid value of the parents is additive, whereas a transcript whose hybrid gene expression value resembles more closely one parent or another is dominant. $\delta / \alpha=0$ corresponds to a state of perfect within-locus additivity (i.e.; $\delta=0$ ) and $\delta / \alpha=1$ or -1 corresponds to complete dominance. According to logic and an assumption used by Renaut et al. (2009) in halving the intervals, we can presume that transcripts resemble:

- Additivity if $-0.5<\delta / \alpha<0.5$

- Paternal/Wild dominance if $-1.5<\delta / \alpha<-0.5$

- Maternal/Domesticated dominance if $0.5<\delta / \alpha<1.5$

- Overdominance if $\delta / \alpha$ falls out of the interval $-1.5-1.5$

According to our results (Figure 4), most transcripts found to be differentially expressed between stocks showed either additive; $48 \%$ and $45 \%$ or maternal/domesticated dominant; $52 \%$ and $42.2 \%$ heritance patterns in sac fry and feeding fry respectively. In addition, $6.1 \%$ of transcripts were paternal dominant and $6.7 \%$ were overdominant in the feeding stage. Among the overdominant transcripts, the ones considered to be more similar to the mother's expression were approximately three times more abundant than the ones found to be closer to the father's. Additivity, as an important mode of inheritance between diverged intraspecific populations, has been reported in previous gene expression studies conducted on wild and domesticated salmon [65] and brook charr [70] as well as on dwarf and normal lake white fish [71]. Additive genetic variation was also found to influence a number of traits in Atlantic salmon such as fitness, survival [3,72], growth and behaviour $[34,36,72]$. In addition to additivity, the findings of this study are indicative of the relevance of a dominant inheritance pattern in wild-domesticated hybrids. However, since the hybrids in this study were produced only by crossing a domesticated dam with a wild sire, we are unable to conclude whether the dominance is purely caused by maternal effects or if the domesticated strain has a superior influence on the transcription of the offspring too. The importance of maternal dominance was highlighted by Bougas and colleagues when studying the transcriptional landscape of wild and domesticated brook charr hybrids. Similarly to the results reported here, their comparison of domesticated and anadromous wild fish revealed that $54.3 \%$ of the differentially expressed transcripts exhibited an additive inheritance pattern, $40 \%$ showed maternal, 5\% paternal dominance, and a small number of transcripts were over/under dominant [70]. Contrary to the current findings, Debes et al. reported that $26.8 \%$ of the wild-domesticated Atlantic salmon hybrid transcripts showed wild dominance [65]. There are a number of variables between the experiments that might account for the differences observed between the studies. First, since different tissue types (gill vs whole fry) were used in the studies, tissue specific gene expression might have affected the results. Second it is likely 
that the different parental strains crossed had different genetic architecture, which could have affected the gene expression of the offspring. In addition, Debes et al. report the use of reciprocal hybrids, whereas in this study, hybrid eggs originated only from domesticated animals. Third, since parental effects vary over time, and seem to be most pronounced at the yolk sac resorption stage, and tend to decrease over time, the sampling time-point selected could also have contributed to the gene expression differences of the hybrids [73]. Indeed, in the current study a higher proportion of genes showed a dominant inheritance pattern at the yolk sac stage (52\%) then during exogenous feeding (42\%), suggesting stronger maternal influence at the earlier life stage. Tissue specificity, the time spent under selection pressure and the genetic architecture of the parental strains might have contributed to the disagreement between our results and a study reporting equal additive, recessive and dominant regulation when analysing the heritability of transcription in livers of wild and domesticated rainbow trout [51].

\section{RT-qPCR validation of the results}

Four significantly differentially regulated transcripts were chosen for further investigation via RT-qPCR, based on their p-values and fold changes. In addition, IGF-1 was also included in the RT-qPCR experiment due to its hypothesised functional importance in the process of domestication [35] and despite the fact that no significant gene expression difference was detected for this transcript on the microarray. Although fold changes were generally low, a good correspondence of expression ratio and direction of regulation was obtained between the microarray and RT-qPCR for most genes quantified (Table 3). Consistent with the microarray data, RT-qPCR results also showed no significant difference in expression of IGF-1 between experimental groups. In contrast, Solberg et al. found elevated IGF-1 mRNA levels in domesticated and hybrid Atlantic salmon head kidneys compared to those of wild fish [35]. The disagreement between our results might be due to the different strains, life stages and tissue types (head kidney vs whole fry) used in the studies.

\section{Conclusions}

This study investigated transcriptional differences between wild and domesticated Atlantic salmon at the early life-history stages, before developmental/growth rate between them could substantially influence experimental outcome. According to the results of this study, genetic information processing and translation pathways in particular are up regulated in domesticated fish whereas immune system related pathways are down regulated in the yolk sac stage. During early exogenous feeding, the digestive and endocrine systems as well as carbohydrate, energy and lipid metabolism pathways are more highly expressed in the domesticated strain, while environmental information processing and immune pathways, especially those related to cytokines, are suppressed compared to those of wild stock.

While sampling complications following growth divergence between stocks need to be considered, it is important to study different life-stages to explore developmental state-specific differences between wild and domesticated individuals and the possible influence of common rearing on gene expression (i.e. translocation of wild fish into a hatchery environment). This study re-enforces the necessity of studying reciprocal hybrids in order to differentiate between maternal (and potentially epigenetic) and domestication effects influencing heritability. Finally, these data support the view that the effect of introgression is highly dependent on the population specific genetic architectures of the crosses $[41,51,74]$, thus studies conducted on multiple strains are essential to draw general conclusions regarding the outcome of genetic interactions between wild and farmed fish.

\section{Availability of supporting data}

Details of microarray experiment have been submitted to ArrayExpress under accession number E-MTAB-2578 and

Table 3 A comparison of gene expression ratios of domesticated and hybrid salmon with respect to wild individuals evaluated using RT-qPCR and microarray analysis

\begin{tabular}{|c|c|c|c|c|c|c|c|c|}
\hline \multirow[b]{3}{*}{ Target } & \multicolumn{4}{|c|}{ Sac fry } & \multicolumn{4}{|c|}{ Feeding fry } \\
\hline & \multicolumn{2}{|c|}{ Domesticated } & \multicolumn{2}{|c|}{ Hybrid } & \multicolumn{2}{|c|}{ Domesticated } & \multicolumn{2}{|c|}{ Hybrid } \\
\hline & RT-qPCR & MA & RT-qPCR & MA & RT-qPCR & MA & RT-qPCR & MA \\
\hline $\mathrm{MHCll}$ & -1.48 & -1.37 & $(-1.17)$ & $(-1.10)$ & -1.95 & -2.09 & -1.24 & -1.38 \\
\hline EPHX & 1.27 & 2.24 & 1.20 & 1.57 & 1.23 & 2.08 & 1.20 & 1.55 \\
\hline IGF & -1.11 & (1.39) & $(1.01)$ & $(1.56)$ & $(1.08)$ & $(-1.14)$ & $(1.05)$ & (1.79) \\
\hline Pesc & $(1.02)$ & 2.82 & $(1.03)$ & 1.91 & -1.15 & 2.43 & -1.10 & (1.36) \\
\hline Poly10 & -2.31 & -6.72 & -1.28 & $(-1.78)$ & -1.61 & -3.19 & -1.28 & -1.63 \\
\hline
\end{tabular}

Microarray values are based on T-tests (unpaired unequal variance, $p \leq 0.01$ and FC $>=1.3$ ), whereas RT-qPCR ratios were obtained by REST2009 ( $p \leq 0.05$ ). Non-significant values are shown in parenthesis. Ratios lower than 1 are expressed as -1 /ratio to obtain an equivalent value to ratios above 1 . 
are accessible at www.ebi.ac.uk/arrayexpress/experiments/ E-MTAB-2578/. The recording of the microarray experimental metadata complies with Minimum Information About a Microarray Experiment (MIAME) guidelines.

\section{Additional files}

Additional file 1: Details of the RT-qPCR validation. Data consists of sequence information for the RT-qPCR primers, the results of the RT-qPCR, including the output of REST and a comparison of the microarray and RT-qPCR results,

Additional file 2: Heritability data. The list of genes the heritability scatter graph is based on, including their significance values, normalized intensity values and annotations.

\section{Competing interests}

The authors declare that they have no competing interests.

\section{Authors' contributions}

BB carried out the laboratory work, the data analysis and drafted the manuscript. JEB participated in the experimental design and the data analysis. KAG participated in the experimental design, producing the crosses and carrying out the sampling. JBT participated in the experimental design and the laboratory work. All authors read, contributed to, and approved the final manuscript.

\section{Acknowledgements}

This study was financed by the Norwegian Research Council project INTERACT. We would like to thank Lise Dyrhovden and Ivar Helge Matre for their assistance in producing the fish upon which the current study is based, Jacqueline Ireland for laboratory technical advice and Drs Stephen Carmichael and Christian De Santis for inspiring discussion regarding microarray data analysis.

\section{Author details}

'Institute of Aquaculture, School of Natural Sciences, University of Stirling, Stirling FK9 4LA, UK. ${ }^{2}$ Institute of Marine Research, Population genetics, PO Box 1870, N-5817 Bergen, Norway.

Received: 17 May 2014 Accepted: 29 September 2014

Published: 9 October 2014

\section{References}

1. Hindar K, Ryman N, Utter F: Genetic Effects of Cultured Fish on Natural Fish Populations. Can J Fish Aquat Sci 1991, 48:945-957.

2. Naylor R, Hindar K, Fleming I, Goldburg R, Williams S, Volpe J, Whoriskey F, Eagle J, Kelso D, Mangel M: Fugitive Salmon: Assessing the Risks of Escaped Fish from Net-Pen Aquaculture. Bioscience 2005, 55:427.

3. Ferguson A, Fleming IA, Hindar K, Skaala O, McGinnity P, Cross T, Prodohl P: Farm escapees. In Atl Salmon Genet Conserv Manag. Edited by Verspoor E, Stradmeyer L, Nielsen J. Oxford: Blackwell Publishing Ltd; 2007:357-398.

4. Glover KA, Skilbrei OT, Skaala Ø: Genetic assignment identifies farm of origin for Atlantic salmon Salmo salar escapees in a Norwegian fjord. ICES J Mar Sci 2008, 65(6):912-920.

5. Glover K: Forensic identification of fish farm escapees: the Norwegian experience. Aquac Environ Interact 2010, 1:1-10.

6. Zhang Z, Glover K, Wennevik V, Svåsand T, Sørvik GE, Fiske P, Karlsson S, Skaala $\varnothing$ : Genetic analysis of Atlantic salmon captured in a netting station reveals multiple escapement events from commercial fish farms. Fish Manag Ecol 2013, 20:42-51.

7. Seagrov H, Urdal K: Escaped Farmed Salmon in the Sea and Rivers; Numbers and Origin. Bergen, Norway: Rådgivende Biologer AS; 2006. Report 947/06, 21.

8. Skilbrei O: Reduced migratory performance of farmed Atlantic salmon post-smolts from a simulated escape during autumn. Aquac Environ Interact 2010, 1:117-125.

9. Skilbrei O: Adult recaptures of farmed Atlantic salmon post-smolts allowed to escape during summer. Aquac Environ Interact 2010, 1:147-153.
10. Gausen D, Moen V: Large-Scale Escapes of Farmed Atlantic Salmon (Salmo salar) into Norwegian Rivers Threaten Natural Populations. Can J Fish Aquat Sci 1991, 48:426-428.

11. Fiske $P$, Lund $R$, Hansen $L$ : Relationships between the frequency of farmed Atlantic salmon, Salmo salar L., in wild salmon populations and fish farming activity in Norway, 1989-2004. ICES J Mar Sci 2006, 63:1182-1189.

12. Webb JH, Youngson AF, Thomson CE, Hay DW, Donaghy MJ, McLaren IS: Spawning of escaped farmed Atlantic salmon, Salmo salar L., in western and northern Scottish rivers: egg deposition by females. Aquac Res 1993 24:663-670

13. Youngson AF, Webb JH, Maclean JC, Whyte BM: Short communication Frequency of occurrence of reared Atlantic salmon in Scottish salmon fisheries. ICES J Mar Sci 1997, 54:1216-1220.

14. Walker A, Beveridge M, Crozier W, Omaoileidigh N, Milner N: Monitoring the incidence of escaped farmed Atlantic salmon, Salmo salar L., in rivers and fisheries of the United Kingdom and Ireland: current progress and recommendations for future programmes. ICES J Mar Sci 2006, 63:1201-1210

15. Gudjonsson S: Occurrence of reared salmon in natural salmon rivers in Iceland. Aquaculture 1991, 98:133-142.

16. Volpe JP, Taylor EB, Rimmer DW, Glickman BW: Evidence of Natural Reproduction of in a Salmon Atlantic Aquaculture-Escaped British Columbia River Coastal. Conserv Biol 2014, 14:899-903.

17. Morris MRJ, Fraser DJ, Heggelin AJ, Whoriskey FG, Carr JW, O'Neil SF, Hutchings J: Prevalence and recurrence of escaped farmed Atlantic salmon (Salmo salar) in eastern North American rivers. Can J Fish Aquat Sci 2008, 65:2807-2826.

18. Fleming AIA, Jonsson B, Gross MR, Lamberg A, Fleming IA: An experimental study of the reproductive behaviour and success of farmed and wild Atlantic salmon (Salmo salar). J Appl Ecol 1996, 33:893-905.

19. Fleming I, Hindar K, Mjøønerød IB, Jonsson B, Balstad T, Lamberg A: Lifetime success and interactions of farm salmon invading a native population. Proc Biol Sci 2000, 267:1517-1523.

20. Webb JH, Hay DW, Cunningham PD, YAF: The spawning behaviour of escaped farmed and wild adult Atlantic salmon (\& imo sakzr L .) in a northern Scottish river. In Aquaculture; 1991:97-110.

21. Crozier WW: Evidence of genetic interaction between escaped farmed salmon and wild Atlantic salmon (Salmo salar L.) in a Northern Irish river. Aquaculture 1993, 113:19-29.

22. Clifford SL, McGinnity P, Ferguson A: Genetic changes in Atlantic salmon (Salmo salar) populations of Northwest Irish rivers resulting from escapes of adult farm salmon. Can J Fish Aquat Sci 1998, 55:358-363.

23. Skaala O, Wennevik $V$, Glover $K$ : Evidence of temporal genetic change in wild Atlantic salmon, Salmo salar L., populations affected by farm escapees. ICES J Mar Sci 2006, 63:1224-1233.

24. Glover K, Quintela M, Wennevik V, Besnier F, Sørvik AGE, Skaala Ø: Three decades of farmed escapees in the wild: a spatio-temporal analysis of Atlantic salmon population genetic structure throughout Norway. PLoS One 2012, 7:e43129.

25. Glover KA, Pertoldi C, Besnier F, Wennevik V, Kent M, Skaala Ø: Atlantic salmon populations invaded by farmed escapees: quantifying genetic introgression with a Bayesian approach and SNPs. BMC Genet 2013, 14:74.

26. Taylor EB: A review of local adaptation in Salmonidae, with particular reference to Pacific and Atlantic salmon. Aquaculture 1991, 185-207.

27. McGinnity P, Prodohl P, Maoileidigh NO, Hynes R, Cotter D, Baker N, O'Hea $B$, Ferguson A: Differential lifetime success and performance of native and non-native Atlantic salmon examined under communal natural conditions. J Fish Biol 2004, 65(SUPPL. A):173-187.

28. Garcia de Leaniz C, Fleming I, Einum S, Verspoor E, Jordan WC, Consuegra S, Aubin-Horth N, Lajus D, Letcher BH, Youngson F, Webb JH, Vøllestad L, Villanueva B, Ferguson A, Quinn TP: A critical review of adaptive genetic variation in Atlantic salmon: implications for conservation. Biol Rev Camb Philos Soc 2007, 82:173-211.

29. Fraser DJ, Weir LK, Bernatchez L, Hansen MM, Taylor EB: Extent and scale of local adaptation in salmonid fishes: review and meta-analysis. Heredity (Edinb) 2011, 106:404-420.

30. Gjedrem T, Gjoen HN, Gjerde B: Genetic origin of Norwegian farmed Atlantic salmon. Aquaculture 1991, 41-50.

31. Gjedrem T: Genetic improvement of cold-water fish species. Aquac Res 2000, 31(1):25-33. 
32. Gjedrem $\mathrm{T}$ : The first family-based breeding program in aquaculture. Rev Aquac 2010, 2:2-15.

33. Thodesen J, Grisdale-Helland B, Helland SJ, Gjerde B: Feed intake, growth and feed utilization of offspring from wild and selected Atlantic salmon (Salmo salar). Aquaculture 1999, 180:237-246.

34. Glover K, Ottera H, Olsen R, Slinde E, Taranger G, Skaala O: A comparison of farmed, wild and hybrid Atlantic salmon (Salmo salar L.) reared under farming conditions. Aquaculture 2009, 286:203-210,

35. Solberg MF, Kvamme BO, Nilsen F, Glover K: Effects of environmental stress on mRNA expression levels of seven genes related to oxidative stress and growth in Atlantic salmon Salmo salar L. of farmed, hybrid and wild origin. BMC Res Notes 2012, 5:672.

36. Solberg MF, Skaala Ø, Nilsen F, Glover KA: Does domestication cause changes in growth reaction norms? A study of farmed, wild and hybrid Atlantic salmon families exposed to environmental stress. PLoS One 2013, 8:e54469.

37. Einum S, Fleming I: Genetic divergence and interactions in the wild among native, farmed and hybrid Atlantic salmon. J Fish Biol 1997, 50:634-651.

38. Norris AT, Bradley DG, Cunningham EP: Microsatellite genetic variation between and within farmed and wild Atlantic salmon (Salmo salar) populations. Aquaculture 1999, 180(3-4):247-264.

39. Skaala $\varnothing$, Høyheim B, Glover K, Dahle G: Microsatellite analysis in domesticated and wild Atlantic salmon (Salmo salar L.): allelic diversity and identification of individuals. Aquaculture 2004, 240:131-143.

40. Roberge C, Einum S, Guderley H, Bernatchez L: Rapid parallel evolutionary changes of gene transcription profiles in farmed Atlantic salmon. $\mathrm{Mol}$ Ecol 2006, 15:9-20

41. Roberge C, Normandeau E, Einum S, Guderley H, Bernatchez L: Genetic consequences of interbreeding between farmed and wild Atlantic salmon: insights from the transcriptome. Mol Ecol 2008, 17:314-324.

42. Mcginnity P, Stone C, Taggart JB, Cooke D, Cotter D, Hynes R, Mccamley C, Cross T, Ferguson A: Genetic impact of escaped farmed Atlantic salmon (Salmo salar $L$.) on native populations: use of DNA profiling to assess freshwater performance of wild, farmed, and hybrid progeny in a natural river environment. ICES J Mar Sci 1997, 54(6):998-1008.

43. McGinnity P, Prodöhl P, Ferguson A, Hynes R, Maoiléidigh NO, Baker N, Cotter D, O'Hea B, Cooke D, Rogan G, Taggart J, Cross T: Fitness reduction and potential extinction of wild populations of Atlantic salmon, Salmo salar, as a result of interactions with escaped farm salmon. Proc Biol Sci 2003, 270:2443-2450.

44. Skaala $\varnothing$, Glover KA, Barlaup BT, Svåsand T, Besnier F, Hansen MM, Borgstrøm R, Fleming l: Performance of farmed, hybrid, and wild Atlantic salmon (Salmo salar) families in a natural river environment. Can J Fish Aquat Sci 2012, 69:1994-2006.

45. Araki $\mathrm{H}$, Berejikian B, Ford MJ, Blouin MS: Fitness of hatchery-reared salmonids in the wild. Evol Appl 2008, 1:342-355.

46. Araki H, Schmid C: Is hatchery stocking a help or harm? Aquaculture 2010, 308:S2-S11.

47. King M, Wilson AC: Evolution at Two Levels in Humans and Chimpanzees. Science 1975, 188(4184):107-116.

48. Carroll SB: Evolution at two levels: on genes and form. PLoS Biol 2005, 3:e245.

49. Schalburg Von KR, Rise ML, Cooper G, Brown GD, Gibbs R, Nelson CC, Davidson WS, Koop BF: Fish and chips: various methodologies demonstrate utility of a 16,006-gene salmonid microarray. BMC Genomics 2005, 6:126.

50. Taggart JB, Bron JE, Martin S a M, Seear PJ, Høyheim B, Talbot R, Carmichael SN, Villeneuve LN, Sweeney GE, Houlihan DF, Secombes CJ, Tocher DR, Teale J: A description of the origins, design and performance of the TRAITS-SGP Atlantic salmon Salmo salar L. cDNA microarray. J Fish Biol 2008, 72:2071-2094.

51. White SL, Sakhrani D, Danzmann RG, Devlin RH: Influence of developmental stage and genotype on liver mRNA levels among wild, domesticated, and hybrid rainbow trout (Oncorhynchus mykiss). BMC Genomics 2013, 14:673.

52. Glover K, Skår C, Christie KE, Glette J, Rudra H, Skaala Ø: Size-dependent susceptibility to infectious salmon anemia virus (ISAV) in Atlantic salmon (Salmo salar L.) of farm, hybrid and wild parentage. Aquaculture 2006, 254:82-91

53. LUND RA, HANSEL LP: Identification of wild and reared Atlantic salmon, Salmo salar L., using scale characters. Aquac Res 1991, 22:499-508.
54. Tacchi L, Bickerdike R, Douglas A, Secombes CJ, Martin S a M: Transcriptomic responses to functional feeds in Atlantic salmon (Salmo salar). Fish Shellfish Immunol 2011, 31:704-715

55. Luo W, Friedman MS, Shedden K, Hankenson KD, Woolf PJ: GAGE: generally applicable gene set enrichment for pathway analysis. BMC Bioinformatics 2009, 10:161

56. Warnes AGR, Bolker B, Bonebakker L, Huber W, Liaw A, Lumley T, Magnusson A, Moeller S, Schwartz M, Venables B, Warnes MGR: gplots: Various R programming tools for plotting data; 2014. http://cran.r-project.org/ web/packages/gplots/index.html.

57. Wickham H: ggplot2: Elegant graphics for data analysis. Springer: New York; 2009.

58. Pfaffl MW, Horgan GW, Dempfle L: Relative expression software tool (REST) for group-wise comparison and statistical analysis of relative expression results in real-time PCR. Nucleic Acids Res 2002, 30:e36.

59. Bougas $B$, Audet $C$, Bernatchez $L$ : The influence of parental effects on transcriptomic landscape during early development in brook charr (Salvelinus fontinalis, Mitchill). Heredity (Edinb) 2013, 110:484-491.

60. Mennigen J, Skiba-Cassy S, Panserat S: Ontogenetic expression of metabolic genes and microRNAs in rainbow trout alevins during the transition from the endogenous to the exogenous feeding period. J Exp Biol 2013, 216(Pt 9):1597-1608.

61. Bernatchez L, Renaut S, Whiteley AR, Derome N, Jeukens J, Landry L, Lu G, Nolte AW, Ostbye K, Rogers SM, St-Cyr J: On the origin of species: insights from the ecological genomics of lake whitefish. Philos Trans R Soc Lond B Biol Sci 2010, 365:1783-1800.

62. Glover K a, Bergh $\varnothing$, Rudra H, Skaala Ø: Juvenile growth and susceptibility to Aeromonas salmonicida subsp. salmonicida in Atlantic salmon (Salmo salar L.) of farmed, hybrid and wild parentage. Aquaculture 2006, 254:72-81.

63. Fleming I, Agustsson T: Effects of domestication on growth physiology and endocrinology of Atlantic salmon (Salmo salar). J Fish 2002. 1330:1323-1330

64. Tymchuk W, Sakhrani D, Devlin R: Domestication causes large-scale effects on gene expression in rainbow trout: analysis of muscle, liver and brain transcriptomes. Gen Comp Endocrinol 2009, 164:175-183.

65. Debes PV, Normandeau E, Fraser DJ, Bernatchez L, Hutchings JA Differences in transcription levels among wild, domesticated, and hybrid Atlantic salmon (Salmo salar) from two environments. Mol Ecol 2012. 21:2574-2587.

66. Martinez V, Dettleff P, Lopez P, Fernandez G, Jedlicki A, Yañez JM, Davidson WS: Assessing footprints of selection in commercial Atlantic salmon populations using microsatellite data. Anim Genet 2013, 44:223-226.

67. Kawai T, Akira S: Signaling to NF-kappaB by Toll-like receptors. Trends Mol Med 2007, 13:460-469

68. Tort L: Stress and immune modulation in fish. Dev Comp Immunol 2011, 35:1366-1375

69. Alejo A, Tafalla C: Chemokines in teleost fish species. Dev Comp Immunol 2011, 35:1215-1222.

70. Bougas B, Granier S, Audet C, Bernatchez L: The transcriptional landscape of cross-specific hybrids and its possible link with growth in brook charr (Salvelinus fontinalis Mitchill). Genetics 2010, 186:97-107.

71. Renaut S, Nolte W, Bernatchez L: Gene expression divergence and hybrid misexpression between lake whitefish species pairs (Coregonus spp. Salmonidae). Mol Biol Evol 2009, 26:925-936.

72. Fraser DJ, Houde ALS, Debes PV, O'Reilly P, Eddington JD, Hutchings J: Consequences of farmed-wild hybridization across divergent wild populations and multiple traits in salmon. Ecol Appl 2010, 20:935-953.

73. Bougas B, Normandeau E, Audet C, Bernatchez L: Linking transcriptomic and genomic variation to growth in brook charr hybrids (Salvelinus fontinalis, Mitchill). Heredity (Edinb) 2013, 110:492-500.

74. Normandeau E, Hutchings J, Fraser DJ, Bernatchez L: Population-specific gene expression responses to hybridization between farm and wild Atlantic salmon. Evol Appl 2009, 2:489-503.

doi:10.1186/1471-2164-15-884

Cite this article as: Bicskei et al:: A comparison of gene transcription profiles of domesticated and wild Atlantic salmon (Salmo salar L.) at early life stages, reared under controlled conditions. BMC Genomics 2014 15:884 